\title{
LABORATORIES
}

Additions and changes since publication of list of laboratories in Volume 2, (1960).

\section{New Laboratories}

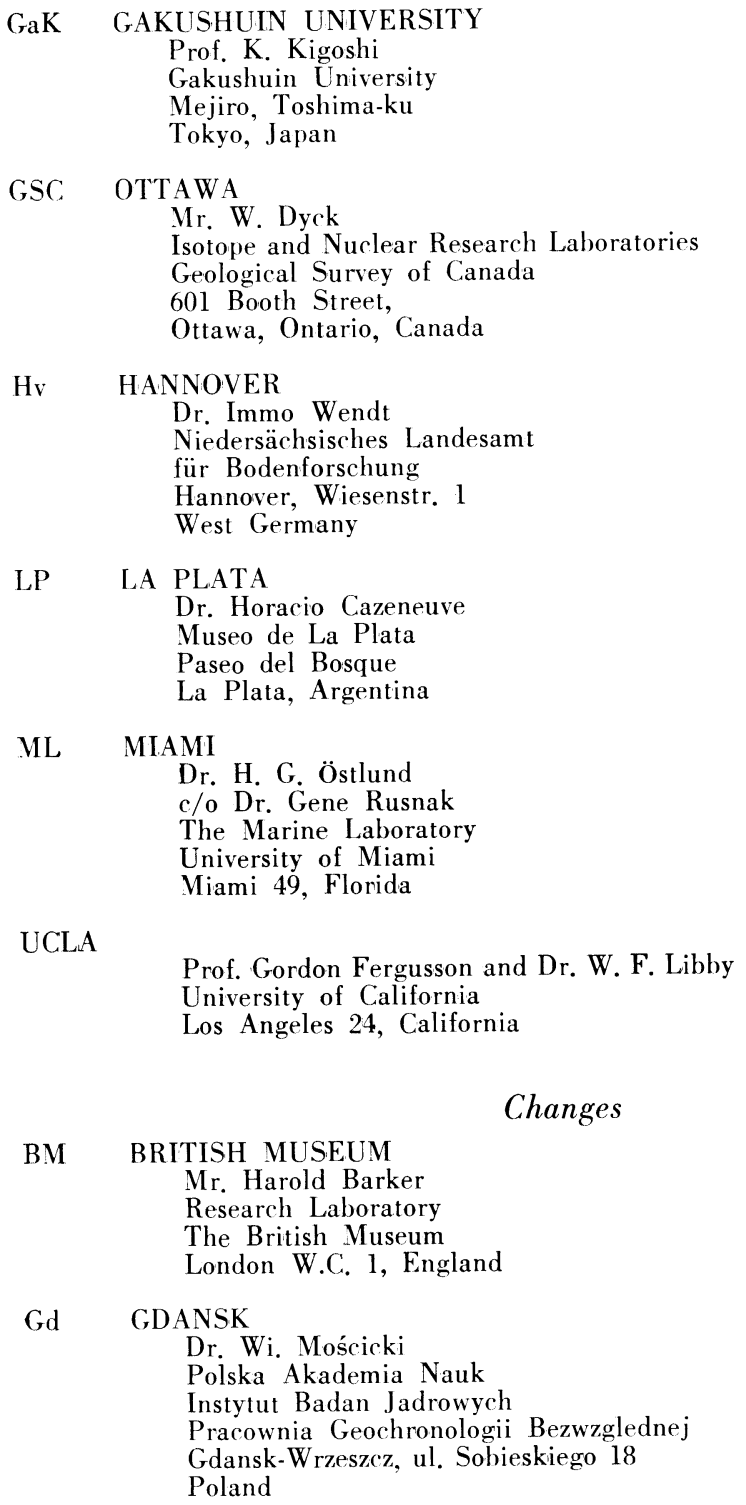

Gd

\section{GDANSK}

Dr. Wi. Mościcki

Polska Akademia Nauk

Instytut Badan Jadrowych

Pracownia Geochronologii Bezwzglednej

Gdansk-Wrzeszcz, ul. Sobieskiego 18

Poland 


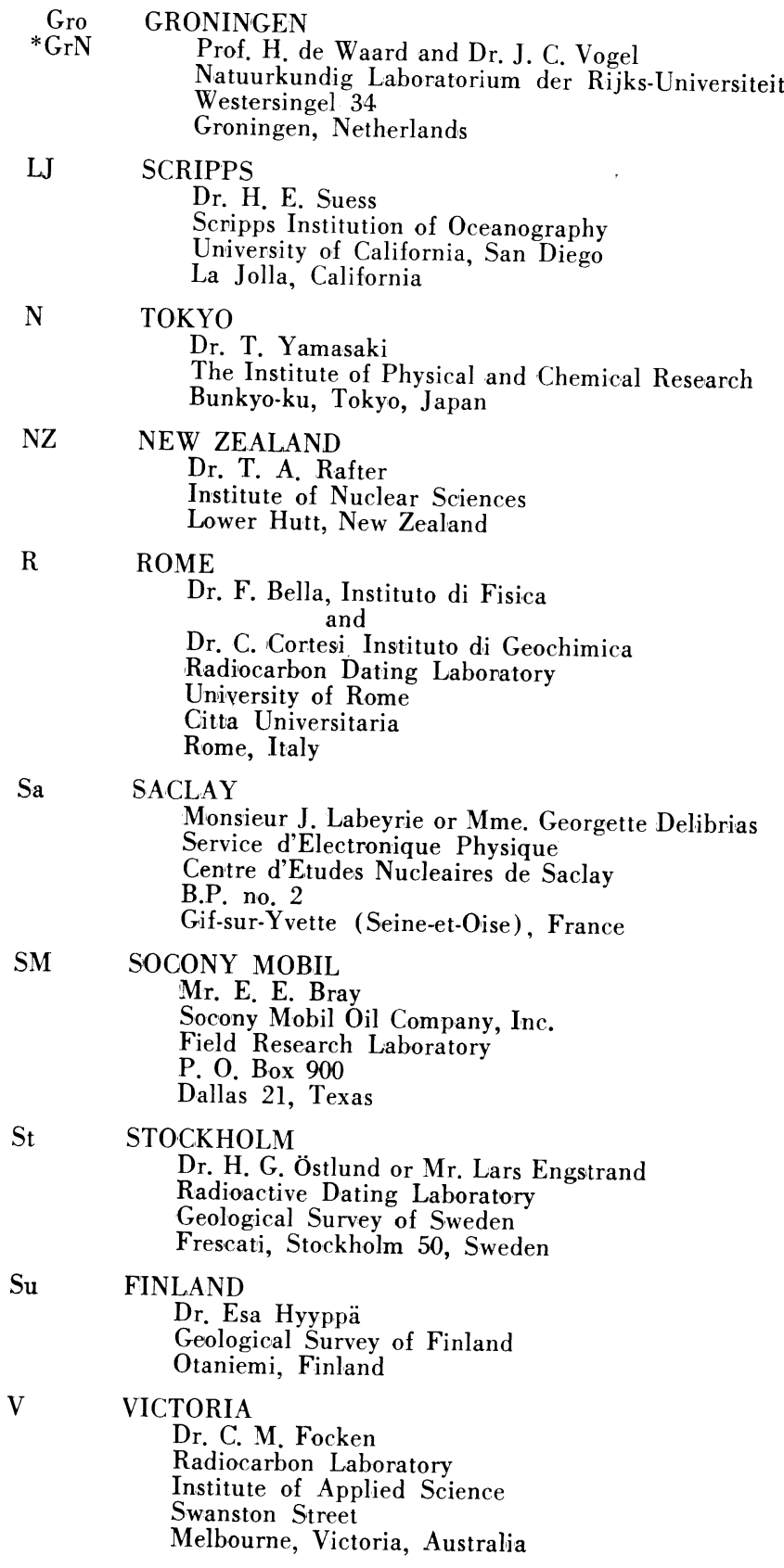

* From January 1, 1961 the Gro numbers have been replaced by GrN numbers. "New" dates are referred to the NBS oxalic-acid standard. 